University of California, Hastings College of the Law UC Hastings Scholarship Repository

Faculty Scholarship

1996

\title{
Combating Impunity: Some Thoughts on the Way Forward
}

Naomi Roht-Arriaza

UC Hastings College of the Law, rohtarri@uchastings.edu

Follow this and additional works at: http://repository.uchastings.edu/faculty_scholarship

Part of the Intellectual Property Law Commons, and the International Law Commons

\section{Recommended Citation}

Naomi Roht-Arriaza, Combating Impunity: Some Thoughts on the Way Forward, 59 Law \& Contemp. Probs. 93 (1996).

Available at: http://repository.uchastings.edu/faculty_scholarship/695

This Article is brought to you for free and open access by UC Hastings Scholarship Repository. It has been accepted for inclusion in Faculty Scholarship

by an authorized administrator of UC Hastings Scholarship Repository. For more information, please contact marcusc@uchastings.edu. 


\title{
Faculty Publications \\ UC Hastings College of the Law Library
}

\author{
Author: Naomi Roht-Arriaza \\ Source: $\quad$ Law \& Contemporary Problems \\ Citation: $\quad 59$ Law \& Contemp. Probs. 93 (1996). \\ Title: $\quad$ Combating Impunity: Some Thoughts on the Way Forward
}

Originally published in LAW \& CONTEMPORARY PROBLEMS. This article is reprinted with permission from LAW \& CONTEMPORARY PROBLEMS and Duke Law School. 


\title{
COMBATING IMPUNITY: SOME THOUGHTS ON THE WAY FORWARD
}

\author{
NAOMI ROHT-ARRIAZA
}

\section{I \\ INTRODUCTION: SOME RECENT ADVANCES}

The very fact that an international meeting of experts convenes to consider the issue of impunity for international crimes and serious violations of human rights is itself a measure of changing times. Although some legal obligations to investigate, prosecute, and punish perpetrators or compensate victims already existed, ${ }^{1}$ until the 1990s the issue was not on the agenda of either the human rights community or states. The last ten years has seen a sea change, prompted both by the end of the cold war and by recognition that the seeds of future violations are sown, in part, in the failure to come to terms with past cycles of violations. Accountability is now routinely demanded and assessed by international human rights groups, and anti-impunity measures are no longer seen as simply a question of national choice. The United States now announces that accountability is a mainstay of its foreign policy, especially in situations of transition. The U.S. State Department Country Reports now refer to impunity as a major problem in a number of countries. The Ad-hoc Tribunals on the Former Yugoslavia and Rwanda ${ }^{2}$ have, of course, helped advance the law by signaling, at least in theory, that certain international crimes must be prosecuted. And the creation of an International Criminal Court is finally firmly on the agenda, with a Diplomatic Conference scheduled for 1998 and a series of Preparatory Committee meetings this year.

On a national level, courts and legislatures have begun grappling with the issues of impunity and amnesty. Recent amnesty laws in South Africa and

Copyright (C) 1997 by Law and Contemporary Problems
*Professor of Law, University of California, Hastings.

1. These included obligations to prevent and punish genocide, see Convention on the Crime of Genocide, G.A. Res. 96, U.N. GAOR, 1st Sess., pt. 2, 55th Plen. Mtg., at 188-89, 78 U.N.T.S. 277 , arts. 4, 5 (1946); to investigate and prosecute grave breaches of the Geneva Conventions, see, e.g., Geneva Convention Relative to the Protection of Civilian Persons in Time of War, of Aug. 12, 1949, pt. IV, $\S 1$, arts. 148, 149 (1949); to investigate, prosecute and compensate cases of torture, see Convention Against Torture and Other Cruel, Inhuman or Degrading Treatment or Punishment, opened for signature Feb. 4, 1985, U.N. GAOR, 39th Sess., Supp. No. 51, at 197, U.N. Doc. A/39/51 (1984), reprinted in 23 I.L.M. 1027 (1984). They also included obligations derived from general international human rights instruments, as discussed infra notes 6-9 and accompanying text. For a fuller discussion, see IMPUNITY AND HUMAN RIGHTS IN INTERNATIONAL LAW AND PRACTICE (Roht-Arriaza ed., 1995).

2. See Security Council Res. 808, U.N. SCOR, 48th Sess., 3175th mtg., at 1, U.N. Doc. S/Res/808 (1993) (creating Ad-Hoc Tribunal on the Former Yugoslavia); Security Council Res. 955, U.N. SCOR, 49th Sess., 3453rd mtg., at 1, U.N. Doc. S/Res/955 (1994) (creating Rwanda Tribunal). 
Guatemala, while still highly problematic in many respects, have moved away from the blanket pre-conviction amnesties passed in the 1970s and ' 80 s by governments in Latin America. The South African amnesty law does not allow blanket amnesty, but rather requires individuals to come forward on an individual basis and provide complete testimony about the deeds for which they seek amnesty. It is up to the South African Commission on Truth and Reconciliation's Amnesty Committee to decide whether the confessions meet the criteria for amnesty. ${ }^{3}$ In Guatemala, the Congress in December 1996 passed a National Reconciliation Law, ${ }^{4}$ which allows the courts to grant amnesty for certain political and related common crimes committed during the internal armed conflict. The law specifically excludes from amnesty those cases involving forced disappearances, torture, or genocide, as well as crimes that have no statute of limitations. While several issues, including the burden of proof, the time frame for bringing evidence against a request for amnesty, and the meaning of "during the internal armed conflict" remain highly problematic, the law is a step forward with respect to previous Latin American amnesties like those of Chile, Peru, or El Salvador. Much of this progress is due to the work of human rights activists and scholars on legal limitations to grants of impunity.

National tribunals have also considered issues related to impunity in several recent cases, with mixed results. The Honduran Supreme Court, for example, found that an amnesty decree did not apply to illegal detention and attempted murder committed by security agents in the context of a number of forced disappearances and assassinations. ${ }^{5}$ The Court found that it was up to the courts, in any case, to decide if an amnesty applied, and that they could not do so without a full investigation into the underlying alleged crimes.

Lower courts in Chile and Peru have come to the same conclusions, based in part on international law obligations to investigate and prosecute violations. In the Chilean case of Uribe Tamblay and others, a Chilean court found that the Geneva Conventions of 1949, the Convention Against Torture, and the International Covenant on Civil and Political Rights all prohibited application of the 1978 Chilean amnesty decree. However, the case was summarily overturned by the Supreme Court, on grounds that no state of war existed and that the remaining treaty obligations were incurred after the relevant events had taken place. ${ }^{\circ}$ A lower Peruvian court also invalidated that country's 1995 blanket amnesty for security forces, finding it incompatible with the Universal Declaration of Human Rights and the American Convention on Human Rights ("ACHR"). Again, a higher court reversed the ruling on grounds of legislative power and the recognition by the American Convention and the International

3. See Promotion of National Unity and Reconciliation Act 34 of 1995.

4. Ley de Reconciliación Nacional, Dec. 18, 1996, Decreto 145-96, Congreso de la República.

5. See Honduras, Corte Suprema de Justicia, Recurso de Amparo en Revisión, No. 60-96, caso Hernandez Santos y otros (Tegucigalpa Jan. 18, 1996).

6. See Chile, caso Uribe Tamblay y otros, Corte de Apelaciones (Sept. 9, 1994), rev'd, Corte Suprema, recurso de queja 5566 (Oct. 16, 1995).

7. Nov. 22, 1969, 1144 U.N.T.S. 123, 9 I.L.M. 673. 
Covenant on Civil and Political Rights ("ICCPR") of a right to obtain amnesty. ${ }^{8}$

The South African Constitutional Court also upheld the constitutionality of the Truth and Reconciliation Commission's ability to grant amnesty after individual petition, disclosure, and investigation of the acts for which amnesty is requested. The petitioners had argued, inter alia, that the "grave breaches" provisions of the 1949 Geneva Conventions prohibited amnesty. The Court rejected the argument based both on the position of international law in South Africa's constitutional scheme and on the injunction in Protocol II of the Conventions to grant "the broadest possible amnesty."

In addition to a growing domestic court practice, international bodies continue to clarify the extent of a state's international law obligations to investigate, prosecute, and compensate victims of international crimes and serious human rights violations. The general tenor has been to reaffirm and expand on duties to investigate, prosecute, and compensate, and to be critical of amnesties that preclude any of these things. Professor Doug Cassel has described the jurisprudence of the Inter-American Commission on Human Rights and the Inter-American Court, including the Commission's most recent pronouncement finding the Chilean amnesty precluding prosecution of the military to violate the ACHR, despite the existence of both a truth commission and compensation measures for victims. ${ }^{10}$

The United Nations Human Rights Committee continues to develop an extensive set of comments in individual communications, finding that the ICCPR requires states to investigate allegations of violations of human rights, bring to justice the perpetrators, and ensure non-repetition of the crimes. Some commentators have argued that such interpretations are not dispositive because they use the words "should" rather than more mandatory terms, and because they do not specifically require prosecution. ${ }^{11}$ But the first point may be more a reflection of the Committee's mandate to forward its "views" to the states concerned rather than to adjudicate cases. The Committee has recently clarified its views on the second point. In Bautista de Arellana v. Colombia, ${ }^{12}$ the Com-

8. See Lima 16th Penal Chamber, caso Salazar Monroe y otros (June 16, 1995), rev'd, Caso Salazar Monroe, Décima Primera Sala Penal de la Corte Superior de Lima, July 14, 1995. ICCPR, 999 U.N.T.S. 171, 6 I.L.M. 368. The court simply misconstrued the ICCPR and ACHR provisions, which allow for post-conviction amnesty from a sentence of death. ICCPR art. 6(4); ACHR art. 4(6).

9. See The Azanian Peoples Organization (AZAPO) et al. v. South Africa, CCT 17/96, Constitutional Court of South Africa (July 25, 1996). The Court also referred to the practice of creating truth commissions while granting amnesties in several Latin American states to conclude that no customary norm forbade the granting of amnesty in this case. See id. at 23. For a description of the case, see Judith Hippler Bello \& Daniel F. Wilhelm, South Africa: Promotion of National Unity and Reconciliation Act of 1995, 91 AM. J. INT'L L. 360 (1997).

10. See Douglass Cassel, Lessons from the Americas: Guidelines for International Response to Amnesties for Atrocities, 59 LAW \& CONTEMP. PROBS. 205 (Autumn 1996).

11. See Michael Scharf, The Letter of the Law: The Scope of the International Legal Obligations to Prosecute Human Rights Crimes, 59 LAw \& CONTEMP. PROBS. 41 (Autumn 1996).

12. Communication No. 563/1993, Views of the U.N. Human Rights Committee (Oct. 27, 1995). The case concerned a political activist kidnapped and assassinated by armed men. Colombia eventually disciplined the police and military officers responsible and had the soldiers dismissed from the 
mittee found that disciplinary and administrative remedies were not "adequate and effective" as required by Article 2(3) of the ICCPR. Although it recognized that an individual cannot require a state to prosecute a particular individual, it suggested that anything short of criminal prosecution, at least in cases of serious violations where the perpetrators are known, would not amount to compliance with the Covenant's duty to ensure rights.

Other U.N. bodies have recently turned their attention to issues of impunity. The United Nations Sub-Commission on Prevention of Discrimination and Protection of Minorities, after multi-year studies, has now published draft Principles on the Right to Reparation for Victims of Gross Violations of $\mathrm{Hu}$ man Rights and Humanitarian $\mathrm{Law}^{13}$ and on the Protection and Promotion of Human Rights through Action to Combat Impunity. I will comment further on these below.

\section{II}

\section{AN AGENDA FOR ACTION}

Despite these advances, much remains to be done. Domestic courts still are unfamiliar with much of the recent international law on investigations and amnesties. Too little attention has been paid to local-level responses to impunity. International mediators, officials of the United Nations, of regional bodies, and of key governments still ignore the international obligations of states. The Draft Statute of the International Criminal Court is weak in several areas related to impunity and to the needs of victims and survivors. And the Principles on Action to Combat Impunity, while an important beginning, need clarification and strengthening especially on issues of amnesty and on the interrelationships among truth, justice, and reparation. They can, however, serve as the starting point for a set of guidelines for states, nongovernmental organizations, and others trying to cope with past crimes and serious human rights violations.

\section{A. Work to Strengthen the Knowledge and Sensitivity of Domestic Courts to International Law Principles on Impunity}

Several recent decisions by the highest courts of different states have upheld amnesty laws; in others, decisions on the constitutionality of such laws are pending. A constant of these decisions has been the incomplete or cavalier treatment of international law. Either the state's international law obligations are dismissed as irrelevant, or at most the focus is on humanitarian law, not human rights law.

army, and an administrative tribunal awarded compensation to the family.

13. Sub-Commission on Prevention of Discrimination and Protection of Minorities, Study Concerning The Right To Restitution, Compensation And Rehabilitation For Victims Of Gross Violations Of Human Rights And Fundamental Freedoms, Mr. Theo Van Boven, Special Rapporteur, U.N. Doc. E/CN.4/Sub.2/1992/8 (interim report); E/CN.4/Sub.2/1993/8 (final report); E/CN.4/sub.2/1996/17 (amended principles). 
One particularly troubling aspect of decisions by the South African, Chilean, and Peruvian ${ }^{14}$ courts has been their reliance on Article 6(5) of Protocol II to the 1949 Geneva Convention. That article reads as follows: "At the end of hostilities, the authorities in power shall endeavour to grant the broadest possible amnesty to persons who have participated in the armed conflict, or those deprived of their liberty for reasons related to the armed conflict, whether they are interned or detained." The domestic courts have used this recommendation to find that amnesties, including those granted by military or militarydominated governments for murders, disappearances, and other serious crimes, are consistent with international law. But the placement of the article at the end of a section on penal prosecutions and the language on internees and detainees suggests the drafters were primarily interested in reintegrating insurgents into national life. The International Committee of the Red Cross has interpreted the provision as

the equivalent of what in international armed conflicts is known as "combatant immunity," i.e.[,] the fact that a combatant may not be punished for acts of hostility, including killing enemy combatants, as long as he respected international humanitarian law, and that he has to be repatriated at the end of active hostilities. In noninternational armed conflicts, no such principle exists, and those who fight may be punished, under national legislation, for the mere fact of having fought. Article 6(5) attempts to encourage a release at the end of hostilities for those detained or punished for the mere fact of having participated in hostilities. It does not aim at an amnesty for those having violated international humanitarian law. ${ }^{15}$

Another legal aspect that has troubled some domestic courts is the fact that many states only entered into human rights treaty obligations with the advent of civilian governments-after most of the violations at issue took place. Under the Vienna Convention on the Law of Treaties, ${ }^{16}$ a state is not bound in relation to acts which took place before the date of entry into force of a treaty with respect to that party. Some courts have held, therefore, that challenges to amnesty are invalid because the underlying violations took place before the relevant human rights treaties entered into force. The Inter-American Commission and Court have resolved this issue, in the case of the American Convention, by distinguishing between the underlying acts and the subsequent failure to investigate, provide judicial protection, or find the body. ${ }^{17}$

Given the very mixed results to date in national court decisions dealing with

14. See, e.g., the South African, Chilean, and Peruvian cases cited supra notes 6-9.

15. Letter from Dr. Toni Pfanner, Head of the Legal Dvision, ICRC Headquarters, Geneva, to author (Apr. 15, 1997).

16. 1155 U.N.T.S. 332 , art. 28 (1980).

17. See Inter-American Commission on Human Rights, cases 10.147 et al., 1992-93 Ann. Rep. Int.Am. Comm'n. H. Rts. 41 (1993), reprinted in 13 HUM. RTS. L.J. 336 (1992) (Argentina's amnesty was enacted after ratification of treaty); Inter-American Court on Human Rights, Decision on Preliminary Objections, Blake v. Guatemala, July 2, 1996, reprinted in 23 Revista IIDH 271 (1996) (while forced disappearance itself not actionable, subsequent failure, despite information, to investigate and recover the body makes for a continuing violation which is actionable); Inter-American Court on Human Rights, Decision on Preliminary Objections, Genie Lacayo v. Nicaragua, reprinted in 16 HUM. RTS. L.J. 414 (1995) (while violation of right to life took place before acceptance of court's jurisdiction, subsequent failure to provide judicial protection and a fair trial were within jurisdiction). 
issues of impunity, one urgent task is education of national judiciaries of the relevant international law standards, at least insofar as they exist to date. Amicus briefs in national cases, workshops for national judiciaries, and the like can help make sure that the law being made at a national level is in tune with our efforts on a global level. In addition, a clearinghouse of national experiences, perhaps compiled in tandem with the U.N.'s work on codification, might be useful.

\section{B. Pay More Attention to Local-Level Efforts to Deal with Past Violations of Human Rights}

The complex processes of coming to terms with past crimes or serious human rights violations take place on a number of levels: the international, national, regional, and local. We have paid a good deal of attention to the international level, where the ad-hoc tribunals and future international criminal court are important to deter future violators and reaffirm core principles of international law. We have focused to some degree on the national level, where national truth commissions and compensation bodies as well as prosecutions may contribute to reestablishing the rule of law, reintegrating survivors into the national polity, and allowing a new government to signal its distance from the old practices of impunity. But we have spent too little time thinking about the local (village, town, commune) level, which is where most people, especially in rural societies, experienced the violence and its aftermath. It is possible, for example, that it is the process of gathering information, of survivors telling their stories in local hearings, of having local people taking testimony, that constitutes the most powerful legacy of a truth commission on the local level. In South Africa, for example, the national Truth and Reconciliation Commission has deputized local NGOs to fan out into the country to take testimony from people in those places where the Commission itself will be unable to present itself. In Guatemala, the church has launched its own investigatory project, known as REMHI ${ }^{18}$ which trains local laypersons to take oral testimonies from people in their area, to be used in compiling an unofficial report of the violations of the 1970s and ' $80 \mathrm{~s}$. In general, the involvement of local people in the process of collecting and processing information, rather than simply the involvement of professional staff, may set in motion more sustained processes of coming to terms with the past. In the future, an as-yet unexplored angle will involve building both anti-impunity and reconciliation measures into local development projects. This could be done, for instance, through prohibitions on participation in some projects for those shown to have been involved in past violations, or through requirements for ethnic or political balance in externally funded projects.

A related issue concerns the role of exhumations and reburials. For many people, putting their loved ones to rest with proper ceremonies is a key to

18. REMHI stands for Proyecto Interdiocesano de Recuperacion de la Memoria Histórica (Interdiocesan Project to Recover Historical Memory). 
healing. Exhumations of mass graves or secret cemeteries serve a key function in gathering evidence for future prosecutions. The international community has to date downplayed the importance of such work, refusing, for example, to provide sufficient funds for exhumations of possible mass graves in Bosnia. But they are also important on a local level, together with reburials, ceremonies, and memorials, as part of redress and rehabilitation for survivors and for local communities as a whole. Any systematization of principles or guidelines should grapple more clearly with the interplay among these two functions of exhumations, and more generally with the needs and possible actions at the local level. Just as in other areas of law, we are seeing the importance of the local and place-specific, we should do so here as well.

\section{Guidelines and Principles Should Be Aimed at International and Regional Organizations As Well As States}

One of the main functions of a set of guidelines or principles should be to inform and guide international mediators and negotiators intervening in civil conflicts. The record to date of the United Nations and the Organization of American States in dealing with anti-impunity issues has been less than stellar. Negotiators have weakened anti-impunity provisions in accords to end civil conflicts in Cambodia, Haiti, and elsewhere. While those negotiating the Dayton Accords on the former Yugoslavia and helping to broker the Guatemalan peace settlement have done better, ${ }^{19}$ a set of internal guidelines would help clarify the limits within which negotiations must be conducted and help avoid the temptation to trade short-term potential gains for a long-term continuation of impunity. Such guidelines might also help negotiators and mediators deal with thorny issues such as how to structure a process of truth-seeking that looks at the violations committed by all sides in a conflict, without falling into a false moral equivalency between the state and non-state actors. And guidelines might help assure that the victims and survivors of crimes and serious human rights violations, as well as civil society in general, are not shunted aside during a negotiation process involving the armed parties to conflict, but rather are involved both in designing reparation measures and in discussing the larger shape of any accords. Perhaps a section of a larger set of principles/guidelines could focus on the specific problems of negotiating settlements to internal armed conflicts.

\section{Strengthen the Anti-impunity and Victim-Centered Aspects of the Draft Statute for an International Criminal Court}

In 1994, the International Law Commission ("ILC") completed a draft Statute for an International Criminal Court ("ICC") and submitted it to the

19. In neither case did negotiators permit a blanket amnesty. See U.S. Dept. of State, General Framework Agreement for Peace in Bosnia and Hezegovina, Text of Dayton Peace Agreement Documents of Nov. 21, 1995, art. IX (all parties to cooperate in investigation and prosecution of war crimes and violations of international humanitarian law); Guatemalan Ley de Reconciliacion Nacional, supra note 4. 
U.N. General Assembly. The 1995 General Assembly set up a Preparatory Committee to draft a text and consider arrangements for convening an international conference of plenipotentiaries on the subject. The Preparatory Committee is currently holding meetings and discussions with the goal of convening a diplomatic conference in 1998 to finalize and adopt a convention on an ICC. ${ }^{20}$

Even assuming the most favorable outcome to the deliberations over establishment of an ICC, the court will deal only with a small fraction of cases involving international crimes and serious violations of human rights; problems of jurisdiction, obtaining custody over accused, or the sheer number of potential defendants (as in Rwanda) will assure that most prosecutions will be carried out at the national level. The effort to build the ICC complements, but should not replace, our efforts to create guidelines and principles for use on the national and local levels.

Although the two efforts are proceeding along separate tracks, there are a few places where the current draft of an ICC statute needs clarification and strengthening in order to support and not undermine efforts at the domestic level. One such place is the treatment of domestic decisions to forgo prosecution as the result of a pre-conviction amnesty. Article 35 of the ILC's draft statute holds that the ICC should refrain from proceeding with a matter if a state has investigated and made an "apparently well-founded" decision not to proceed, or if the matter is under investigation, thus giving primary jurisdiction to the domestic courts. The court itself is to decide whether an "effective" and "available" domestic forum exists. Many states have criticized the concept of "effectiveness" of a domestic forum as vague, and it is unclear whether a state that has granted a blanket pre-conviction amnesty would be considered to have made an "apparently well-founded" decision not to prosecute. We should urge the Preparatory Committee to clarify that a domestic amnesty for crimes covered by the ICC's statute would not necessarily preclude international prosecutions for such crimes. ${ }^{21}$ It might be useful to clarify under what conditions a post-conviction pardon, or an individual grant of amnesty pursuant to a confession, might deprive the ICC of jurisdiction. Given the seriousness of the offenses at issue, such circumstances should be quite extraordinary.

The other area where the ILC draft statute falls short is in considering the links between criminal prosecution and civil redress. One suggestion is to consider the institution of a parallel tort action, or a mechanism for victims to act as a "partie civile" and have the civil action brought as part of the criminal prosecution. Another suggestion would include allowing the sentencing chamber to hear evidence from the victims and survivors and to take into account

20. See U.N. General Assembly Resolution on the Establishment of an International Criminal Court, adopted Dec. 17, 1996, U.N. GAOR, 51st Sess., Agenda Item 147, U.N. Doc. A/Res/51/207 (1997).

21. See, e.g., Order de Prisión provisional incondicional de Leopoldo Fortunato Galtieri, Magistrato-Juez del Juzgado no. 5 de la Andrencia Nacional, Madrid, Spain (Mar. 25, 1997) (arrest warrant for Argentine general issued by Spanish court on charges of murder, forced disappearance, and genocide, despite existence of domestic amnesty). 
expressions of remorse, apologies, and efforts made to afford reparations to victims as part of sentencing determinations. An expanded role for a victims and witnesses unit should deal with the material and psychological needs of survivors from the time they are initially contacted by the prosecutor, not only while they are testifying.

E. The Joinet and Van Boven Studies Provide a Convenient Starting Point for a Set of Principles/Guidelines, but They Need Expansion, Strengthening, and Clarification

In considering the way forward, we have the advantage of existing draft principles, which have been elaborated over the last several years under the leadership of two Special Rapporteurs of the U.N. Subcommission for Prevention of Discrimination and Protection of Minorities. Professor Van Boven's study focuses on the right to reparation for victims, ${ }^{22}$ while the Joinet study looks specifically at impunity. ${ }^{23}$ The latter, therefore, is especially relevant as a starting point for principles/guidelines on the subject.

The Joinet study is divided into three parts: the right to know, the right to justice, and the right to reparation. Under the right to know, the study covers extrajudicial commissions of inquiry ${ }^{24}$ and preservation of and access to archives. ${ }^{25}$ The right to justice encompasses general considerations on the duties of states with regard to the administration of justice,$^{26}$ the distribution of jurisdiction between national, foreign, and international courts, ${ }^{27}$ the use of restrictions in areas that might favor impunity such as prescription, ${ }^{28}$ amnesty, ${ }^{29}$ asylum, ${ }^{30}$ extradition, ${ }^{31}$ due obedience, ${ }^{32}$ and the jurisdiction of military courts. ${ }^{33}$ The right to reparation includes general principles ${ }^{34}$ and guarantees of nonrepetition. ${ }^{35}$

Although the initial division into elements of investigation (right to know), prosecution (right to justice), and redress (right to reparations) seems unobjectionable, the intersection and interconnections among these three areas require

22. See Revised Set of Basic Principles and Guidelines on the Right to Reparation for Victims of Gross Violations of Human Rights and Humanitarian Law, 1995/117, U.N. Doc. E/CN.4/Sub.2/1996/17 (1996) (prepared by Special Rapporteur Theo Van Boven pursuant to Sub-Commission decision).

23. See The Administration of Justice and the Human Rights of Detainees, ESCOR, 48th Sess., Annex II, Agenda Item 10, U.N. Doc. E/CN.4/Sub 2/1996/18 (revised final report; author's translation from French text). The Joinet Study is reprinted in Appendix B.

24. See id. Annex II(I)(B), principles 5-12.

25. See id. Annex II(I)(C), principles 13-17.

26. See id. Annex I(II)(A), principle 18.

27. See id. Annex II(II)(B), principles 19-22.

28. See id. Annex II(II)(C), principle 24.

29. See id, principle 25 .

30. See id., principle 26.

31. See id, principle 27.

32. See id., principle 29.

33. See id., principle 31.

34. See id. Annex II(III)(A), principle 33-36.

35. See id. Annex II(III)(B), principles 37-42. 
further elaboration. For example, a credible threat of prosecutions of those not testifying may be necessary to induce perpetrators to testify before a commission of inquiry, as in the South African case. Such commissions can facilitate the work of national and international courts by making evidence available to them, or they can impede future prosecutions by including in their terms of reference a provision that the information gathered may not be used for purposes of prosecution. A successful prosecution might include the obligation to make reparations to victims as part of the criminal sanction, or such reparations might be tied to measures of non-repetition, for instance by creating a fund for survivors paid for by a reduction in the size of the armed forces. It is important to see the three areas as interconnected and indivisible, and not as a menu of possible options.

The current Sub-Commission draft contains a few shortcomings. It has weak provisions regarding the public nature of hearings (principle 12), and seems to make no distinctions between state and non-state actors in terms of the focus of investigation (principle 7), raising dangers that spurious "equivalencies" between the actions of the two groups might be called for. The wording may be read as posing unacceptable limits on an NGO's standing to bring complaints on behalf of victims. Although there are other additions, clarifications, or changes that one might desire in the current draft, it stands as a sound effort on which to build and elaborate. These principles will come before the U.N. Commission on Human Rights in 1998. Without strong NGO support, they are likely to be watered down or, worse, sidelined.

\section{III \\ CONCLUSION}

This list of tasks by no means exhausts what needs to be done by legal scholars and advocates to combat impunity, but it provides a number of starting places. As we move forward to consider a set of principles/guidelines, we would do well to think simultaneously about implementation and reaching our proposed audiences, not simply about norm elaboration. The pathways for implementation are many and overlapping: through domestic courts and legislatures, through the U.N. General Assembly, and through the internal guidelines of international and regional organizations. In addition, we need to keep concentrated pressure on a number of different fora at once, both to avoid backsliding and to develop the law. While resource constraints are a real problem, an exclusive NGO focus on the ICC negotiations may risk real setbacks in other arenas, to the overall detriment of an anti-impunity agenda. As we go forward, one useful model for action is the womens' movement, with its organized and tenacious insistence on the gender aspects of many international instruments, negotiations, and mechanisms. Like the womens' movement, we need to be present in many arenas as well as develop a set of principles to guide states and other international actors. 